UDC 78.087.68

DOI $10.33287 / 22192$

Tarasova Nataliia,

Candidate of Philosophy, Associate Professor of Department „History and Theory of Music" of M. Glinka Dnipropetrovsk Academy of Music phone: (095) 315-35-77 e-mail: tarasova116@ukr.net

Kamuz Polina, Master of Department „History and Theory of Music” of M. Glinka Dnipropetrovsk Academy of Music phone: (097) 132-56-83 e-mail: kamuzpolina11@gmail.com

\title{
CHRISTIAN DUALISM OF CONFESSION AND GLORIFICATION AS THE BASIS OF MUSICAL DRAMATURGY AND STYLISTIC FEATURES OF LITURGY OF ST. JOANNA ZLATOUST BY M. SKORYK
}

The aim of the article is detenction of dramaturgic role inherent to Orthodox liturgical canonical texts and motets of dualism of christian confession and glorification on dramaturgic and stylistic levels of Liturgy of St. I. Zlatoust by M. Skoryk. The canonical structure of Liturgy of St. I. Zlatoust at the level of liturgical texts and motets is investigated; the features of composer's interpretation of characteristic structuralcompositional, harmony mode, texture, thematic methods of transmission of sense of liturgical texts and canonical motets are examined. The methods of the research are based on the use of musically-culturological, comparatively-historical, theoretical-analytical, textological methods. Scientific novelty. For the first time the system analysis of Liturgy St. Joanna Zlatoust 1) in the context of authorial choral style of M. Skorik; 2) in unity of neobargee, neoromantic and neofolklore stylistic principles of composer's thinking; 3 ) in the aspect of cooperation of harmonic, tone mode, form-building means of expression of music of the XX century; 4) at symbolically-semantic level of work is carried out. Conclusions. Sacred choral music became a major landmark in creative heritage of M. Skoryk. Embodiment by the composer of sacral senses of Liturgy 
differs free character sent to opening of typical for Orthodox of dualism confession and glorification, through experiencing of such fundamental religious states, as 1) is personality-dramatic confession, 2) is transcendent contemplativeness, 3 ) is catharsis state, 4) is subjectively-lyric acceptance of Divine will, 5) is glad glorification. Thus, in the process of analysis the originality of authorial interpretation of genre of Liturgy was educed at the level of composition, in correlation with the canonical following of texts and motets, at the level of musical style; connection of musical language of Liturgy by M. Skoryk is argued with neofolklore principles, tone mode and harmonic receptions of music of the XX century.

The key words: Liturgy, glorification, confession, neoclassical tendencies, neofolklore tendencies, bargee repented concert, polytonality, polytone.

Тарасова Наталія Юріївна, кандидат філософських наук, доцент кафедри „Історія та теорія музики” Дніпропетровської академії музики ім. М. Глінки

Камуз Поліна Валеріївна, магістрант кафедри „Історія та теорія музики” Дніпропетровської академії музики ім. М. Глінки

Християнський дуалізм покаяння та славослів'я як основа музичної драматургії і стильових особливостей Літургї̈ Св. Іоанна Златоуста М. Скорика

Мета статті - виявити драматургічну роль властивого православним літургічним канонічним текстам і піснеспівам дуалізму християнського покаяння та славослів'я на драматургічному й стильовому рівнях Літургії Св. Іоанна Златоуста М. Скорика. У роботі вивчається канонічна структура Літургії Св. І. Златоуста на рівні богослужбових текстів і піснеспівів; розглядаються особливості композиторської інтерпретації характерних структурнокомпозиційних, ладо-гармонічних, фактурних, тематичних засобів передачі сенсу літургічних текстів і канонічних піснеспівів. Методи дослідження - музично-культурологічний, порівняльно-історичний, теоретико-аналітичний, а також текстологічний. Наукова новизна. Вперше здійснюється системний аналіз Літургї Св. І. Златоуста 1) у контексті авторського хорового стилю М. Скорика, 2) в єдності необарочних, неоромантичних та неофольклорних стильових принципів мислення композитора, 3) в аспекті взаємодії гармонічних, ладо-тональних, формоутворюючих засобів виразності музики XX століття, 4) на символічно-змістовному рівні твору. Висновки. 
Духовна хорова музика стала найважливішою віхою у творчому доробку М. Скорика. Втілення композитором сакральних змістів Літургії вирізняється вільним характером, спрямованим на розкриття типового для православної ортодоксії дуалізму покаяння та славослів'я, через відчуття таких основоположних релігійних станів як 1) особистісно-драматична спокутуванність, 2) трансцендентна споглядальність, 3) очищуючи-катарсиський стан, 4) суб'єктивноліричне прийняття Божої волі, 5) радісне славослів'я. Таким чином, у процесі аналізу була виявлена оригінальність авторської інтерпретації жанру Літургії на рівні композиції, у співвідношенні з канонічним упорядкуванням текстів і піснеспівів, на рівні музичної стилістики; аргументований зв'язок музичної мови Літургії М. Скорика 3 неофольклорними принципами, ладо-тональними і гармонічними прийомами музики XX століття.

Ключові слова: Літургія, славослів'я, покаяння, неокласичні тенденції, неофольклорні тенденції, барочний спокутуваний концерт, політональність, поліладовість.

Тарасова Наталья Юрьевна, кандидат философских наук, доцент кафедры „История и теория музыки” Днепропетровской академии музыки им. М. Глинки

Камуз Полина Валерьевна, магистрант кафедры „История и теория музыки” Днепропетровской академии музыки им. М. Глинки

Христианский дуализм покаяния и славословия как основа музыкальной драматургии и стилевых особенностей Литургии Св. Иоанна Златоуста М. Скорика

Цель статьи - выявление драматургической роли присущего православным литургическим каноническим текстам и песнопениям дуализма христианского покаяния и славословия на драматургическом и стилевом уровнях Литургии Св. Иоанна Златоуста М. Скорика. В работе исследуется каноническая структура Литургии Св. И. Златоуста на уровне богослужебных текстов и песнопений; рассматриваются особенности композиторской интерпретации характерных структурно-композиционных, ладогармонических, фактурных, тематических способов передачи смысла литургических текстов и канонических песнопений. Методы исследования - музыкально-культурологический, сравнительноисторический, теоретико-аналитический, текстологический. Научная новизна. Впервые осуществляется системный анализ Литургии 
Св. Иоанна Златоуста 1) в контексте авторского хорового стиля М. Скорика, 2) в единстве необарочных, неоромантических и неофольклорных стилевых принципов мышления композитора, 3) в аспекте взаимодействия гармонических, ладо-тональных, формообразующих средств выразительности музыки XX столетия, 4) на символически-смысловом уровне произведения. Выводы. Духовная хоровая музыка стала важнейшей вехой в творческом наследии М. Скорика. Воплощение композитором сакральных смыслов Литургии отличается свободным характером, направленным на раскрытие типичного для православной ортодоксии дуализма покаяния и славословия, через переживание таких основополагающих религиозных состояний, как 1) личностно-драматическая исповедальность, 2) трансцендентная созерцательность, 3) очистительно-катарсическое состояние, 4) субъективно-лирическое принятие Божественной воли, 5) радостное славословие. Таким образом, в процессе анализа была выявлена оригинальность авторской интерпретации жанра Литургии на уровне композиции, в соотношении с каноническим последованием текстов и песнопений, на уровне музыкальной стилистики; аргументирована связь музыкального языка Литургии М. Скорика с неофольклорными принципами, ладо-тональными и гармоническими приёмами музыки ХХ века.

Ключевые слова: Литургия, славословие, покаяние, неоклассические тенденции, неофольклорные тенденции, барочный покаянный концерт, политональность, полиладовость.

Setting of the problem. Radical ideological, value and aesthetic changes in Ukrainian society, culture and art of the 2nd half of the XX-th century took a fresh look at the sphere of sacred music for composers of the "Sixtiers" such as M. Skoryk, L. Dychko, V. Silvestrov, Y.Stankovych. In their creations since the 90s among the chamberinstrumental, orchestral, and musical-stage genres, a special place spiritual choral compositions is occupied. Among them are the Liturgy No. 1 for the homogeneous choir (male, female) 1989, 1990, the Liturgy No. 2 for the mixed choir (1990), ,The Solemn Liturgy” (2000-2002) by L. Dychko; Requiem for Larisa for soloists, mixed choir and orchestra (1999), Liturgical chants (in Ukrainian; 2005) and Two psalms of David (37 and $150 ; 2007)$ for a capella choir by V. Silvestrov; Concert for choir a capella 
on Bible texts (1998), Liturgy of St. I. Zlatoust for mixed choir (2004) by Y. Stankovych.

At this time, M. Skoryk's spiritual-choral works is appeared - for canonical texts are „The Spiritual Concert” (1998, new edition - 2003), three psalms „Chy Ty, mii mylyi Bozhe”, „Ne karay mene, o Hospody” and „Bozhe, spasy mene” (2003), „The liturgy of St. I. Zlatoust” (2005), which testify to the creative maturity of the master. Skoryk's ecclesiastical and choral compositions accumulated a complex of individual style features, in which the combination of deep national-genre traditions with modern means of musical expression is noticeable.

The relevance of the article is in that the sphere of the sacred music turned to God was opened in a culture and art of second half of the XX century. A rehewed religiousness became a stimulus for writing Ukrainian composers of the „Sixtiers” genres of Liturgy, spiritual concert, psalm, repented compositions. As in musicology such area of ideas is not yet exposed, then it inspires on new researches.

The analysis of literature. The relevance of sacred music for performers and composers has stimulated new interest. Among the musicological works that study the spiritual and choral work of modern Ukrainian composers, dissertations and articles by Kovalev and Aleksandrova and Tishchenko are of the greatest value. The first two are devoted to the problem of the relationship between canonical and individual author's beginnings in the liturgies of St. I. Zlatoust; in the latter, the relationship between rite and genre is considered.

The purpose of the work is to reveal the dualism of Christian repentance and glorification as the basis of the musical drama of the Liturgy of St. I. Zlatoust by M. Skoryk.

The object of our research is the genre of the Liturgy of St. I. Zlatoust in the context of spiritual choral music of professional composer creativity. The subject of study is the Liturgy of St. I. Zlatoust by M. Skoryk.

Statement of the base material. During the preparation for the publication of the musical text and the performance of the Liturgy of St. I. Zlatoust by M. Skoryk, the choir „Kyev” the composer shared: ,...to write religious music - it is very grateful to the composer, but at the same time a complicated and responsible matter, because it appeals to the best feelings of a person, must be deep and truthful, therefore, does not involve the superficiality, selflessness of the author in his talent, the supremacy of „genius" to „ordinary" listeners”. But if he is able to tune in to this system, 
to feel the right tone, then he has the chance to unfold like in no other musical genre. This statement describes the attitude of M. Skoryk to spiritual music, as to the exclusive sphere of musical creativity, the sphere of high spiritual responsibility and sincerity, the author's depth of penetration into liturgical texts, and special sincerity in the musical expression of the best feelings of a person turned to God.

Peniteness and Recognition is the spiritual and emotional basis of the Liturgical action; they symbolize the dualism of human nature, the constant struggle of soul and body in it. Therefore, already in the first centuries of Christian dogma in the Byzantine patristics, we find indications of the Christian dualism of repentance and glorification as the basis of liturgical drama. The texts of the Fathers of the Church, who participated in the formation of the Divine Service Canon, testify to this. After the collapse of a single Ecumenical Christian Church and the emergence of Orthodox and Catholic denominations, the idea of dualism of repentance and glorification is specifically implemented in the Catholic Mass, Litany, Penitential psalms and other religious music forms of this denomination.

About the musical and poetic uniqueness of the embodiment of the spiritual-emotional interaction of the religious states of penitence and praise in the Orthodox Liturgy, Christian thinkers clearly demonstrate.

Taking the texts of the Liturgical canon connected with certain chants unchanged, M. Skoryk passes them through the genre prism of the personal dramatic-penitential confession, which takes place in the ritual context of collective liturgical action. It determines the free character of the musical interpretation of the musical-poetic canon.

Formally, the structure of the vocal-choral cycle is numbered. The first one is the external musical one: the level of unity of the cycle structure from the 18 numbers Skoryk's Liturgy is as follows:

1. Velyka yekteniia.

2. Blahoslovy, dushe moya, Hospoda.

3. Yedynorodnyi Synu. Mala yekteniia.

4. U Tsarstvi Tvoyim.

5. Pryiidit, poklonimos.

6. Sviatyi Bozhe.

7. Alyluia.

8. Potriina yekteniia.

9. Kheruvymska pisnia. 
10. Viruiu.

11. Mylist myru. Tebe ospivuiemo.

12. Dostoino ye.

13. Prokhalna yekteniia.

14. Otche nash.

15. My bachyly Svit istynnyi.

16. Nekhai povni budut.

17. Nekhai bude blahoslovene.

18. Slava Ottsu i Synu.

But on the inner level of the musical unity of the cycle, the semantic division of the Liturgy is found, according to the liturgical content, into two parts. These are the Liturgy of the Announced and the Liturgy of the Faithful, which symbolize the Christological dual unity and the dualism of the penitential body-soul, as well as the process of spiritualizing transformation of corporeality together with the acquisition of faith.

1 st part - from the 1 st to the 7 th number;

2nd part - from the 8 th to the 18 th number.

The two-partness indicates the presence of two sacral spheres, which determines the place of each of these parts in the general context of the purpose of the liturgy.

The Liturgy of announced reminds us about the first centuries of Christianity, when people who had not yet received Holy Baptism (that is, the announced ones) were not allowed to attend the Consecration of the Holy Gifts and to Communion. Therefore, the semantic character of the texts of the Liturgy announced can be defined as instructive and preaching. It includes the texts of Psalms 102, 145 (the so-called „figurative”), which are enthusiastically joyful praise and thanksgiving to God for his mercy, especially in regard to sins and help to those who pray.

The sacred sphere of the Liturgy of the faithful is different in character. The text here is less graphic, everything is focused on the celebration of the Divine Eucharist. So, this part of the liturgy can be called prayer-contemplative.

However, the idea of interaction, the constant mutual transition of the state of repentance to glorification, the tragic confession to contemplative tranquility in faith, the intensity of their verbal and intonational-thematic beating, contributes to the through musical realization of the idea of spiritual struggle in the soul of man on the way to faith, complex spiritual work in cross-cutting development the struggle of two musical beginnings. 
The result of this at the level of the number cycle form becomes another form of a higher plan - the continuous development of the confrontation of two beginnings, uniting intonational, thematically and tonal-harmonic logic, putting together 18 cycle numbers. In turn, inside such a through integrity, the outlines of another inner form associated with the symbolism of the trinity are seen. Therefore, the structure of the Liturgy of M. Skoryk is divided into three more small cycles. In particular, a cycle of antiphons, hymns of the Small Entry („Pryidit, poklonimos”, „Sviatyi Bozhe”) and chants of the Eucharistic canon, etc.). These three internal cycles - from the 1 st to the 7 th number, from the 8 th to the 12 th and from the 13 th to the 18 th.

Thus, the three levels of the musical form constitute the internal structural unity of the Skoryk's Liturgy. And at all levels of the form of the Liturgy, the dramatic principle of opposition and unity of the spiritual sentiments of repentance and glorification inherent in the canonical Liturgical action is realized in its own way.

In accordance with this, the cyclical whole of the Liturgy is developed on the basis of a contrast-complex type of drama, built on a dynamic change of contrasting 1) dramatic confessional, penitential in emotional fullness episodes, and 2) prayer-contemplative appeals to God, expressing humble or enthusiastic feelings, states of prayer reverence or the joyful glorification of the Lord.

Such a contrast of states, inherent in individual cycle numbers and the relationship between the numbers, contributes to the development of the numbered discontinuity of the cycle into a musical unity of dramatic action with moments of spiritual enlightenment.

Musical development is united by through dynamic line of transformations of the initial contrasting thematic material (dramatic and contemplative nature).

Continuous thematic transformations from the Liturgy announced to the Liturgy of the faithful, in turn, symbolize the spiritual transformation of the confessing hero and the collective participants in the Liturgy.

The result of a cross-cutting musical development of the Liturgical drama of intonational-shaped tensions between two spheres - confessional repentance and prayer-glorification, and at the same time between two angles of this liturgical process - personal and collective - becomes a musical outcome - the final number of the Liturgy. The result of Skoryk's Liturgy through musical drama is the intonational symbolization of the purification of the repentant soul, deliverance from sinful dramatic 
experiences, spiritualization of physicality with faith, spiritual insight and exaltation with Divine support, the joy of forgiveness of personal selfassertion and strengthening of faith in the future in union with God.

The structural unit of the concentration of the dual unity of penance and glorification in the Liturgy is yektenii. Therefore, in the Liturgy by Skoryk, the significant formative and cross-cutting role of the litigies is yekteniy. Their arrangement in the aftermath creates such elements of the form of the Liturgy as framing, arches, and a bunch.

The idea of repentance and glorification in all the yekteniiakh (Velyka, Mala, Potriina, Prokhalna) is musically brought to the fore. Because the Yektenii is a symbolic form of the collective, conciliar communal unity of the Orthodox in the prayer petition of God for repentance, they have a choral-harmonic nature. Traditionally, composers, authors of the Liturgy, serve Litany in a harmonic style, most often in a strict and modest functional sense. In addition, for each, the harmonic language of Yektenii is peculiar. For example, in the liturgies, by Stetsenko is humbly strict in expression of feelings, concise in melodic movement and form (simple 2-part or song-stanza form), rather simple in terms of harmonic solution. Skoryk emphasizes otherwise the diversity of religious experiences in the content of the yekteniia. For this, he applies the functional logic of polytonal development, the techniques of polyharmonic structures, unexpected polylade transitions, vivid contrasts of the tertiary and non-tierzian structures of diatonic polyaccords.

Cantata chamber Liturgy - becomes the personal confessional tone of the composer. The brightness of the interaction of Christian personal and collective feelings demanded from the composer a musical compositional solution, close to the concert one.

One of the main means of expression of the duality of unity of repentance and glorification in the Liturgy, in music, becomes the harmonic aspect of the musical text. The colorful and phonic sounds of harmonies, specific harmonic structures, the modulation logic of the constructions and the tonal logic of the whole distinguish the main or most important words of the text.

„Alyluia" (7th number) is the apotheosis of the entire first section. The composer rather freely interprets the song of praise, which is usually performed three times according to the liturgical canon. And in creations by Skoryk, it takes the form of a multiplying glorification of God. Praising motive sounds in every voice, expanding to the scale of a large variation form. 
This is a sample of a solemn lyric character. The main key - D major (as a symbol of light and joy), the swift continuous movement in the Allegro tempo, the singing of the choir in parallel thirds, octave doublings, the use of a soft 3-4-voice sound at six/ eight-voices - all this creates a bright enriched folk-song complex in the form varied couplet. In this case, there is a 3-part in the construction of the composition.

The timbral development as an effect of the multitude calling to their Creator is of great importance in this issue. It starts with one low voice, which from the second measure begins to repeat the bass. The following sentence begins in exactly the same way, but in the upper voices, to which canon the bass a re joined. Then comes the choir roll call D-dur / E-dur as a realization of the tradition of anti-background singing.

The second period (A-dur) is implemented according to the same principle as the first, only the voices enter canon not in the third, but in the octave, starting with the soprano (13th beat) and ending with the bass. Then the sound of the choir abruptly forte is replaced by a 6-chorus choir in H-dur (from the 19th to the 25th b.), Where the common outline of the lower and upper voices moves with parallel triads. Then comes a small sequential link, an antiphonic fragment, which leads us to the culmination of the development in Des-dur in an 8-voice sound. In the 37th bar, there is a sharp tonal shift (C-dur). Gradually, everything returns to the initial polyphonic presentation in D- dur.

The timbre, textural, dynamic, tonal contrasts provide an allusion to both the Ukrainian folk carols and choral miniatures of Leontovich („Didu mii, Dudaryku"). The imitations between the choral parts, as well as the constant alternation of syllabic singing with the melodious, emphasizes the effect of the popular liturgical ritual and playful beginning.

The tragic center of experiencing the state of repentance in the Liturgy of Skoryk is the g-moll monologue „Viruiu" (10th number). Prayer, which sets out all the main provisions of the Christian faith, acquires the character of an individual-personal confession.

In everyday liturgical practice, the Creed is executed by all parishioners. Skoryk also makes the spokesman of the personal principle, the solo tenor. The chorus appears in this statement only as a background or supports and continues the soloist, empathizing with him, coinciding with him in a state of repentance. The effect of intense spiritual penitential interaction and reunion in the religious empathy of the personal and the universal arises. 
This number is distinguished by the constant variability of the meter and the change of tonalities. There is no feeling of soil under your feet this is a tireless search for true repentance, although the text contains a statement of faith.

The form is built in a surprising way. Conceptually, the composer accurately draws up the musical canvas, according to the canonical division of the creed into three sections. Although making their own adjustments. So, the first section g-moll (26 tons) performs the tenor (chorus - sounding chord background), and then an abbreviated reprise performed by the choir (18 b.), which ends with the D-dur key. The only difference occurs at the beginning, when the word „Viruiu" sounds three times at the lower voices, then at the top and at the solo voice. The idea of holiness will always be expressed by Skoryk through the trinity, especially when faith in the Triune God is confessed.

The middle section ,Win dlia nas, liudei...” begins with the 45 th beat in a solo voice in Fis-dur. It emphasizes the exacerbated harmonies of the word about crucifixion and suffering. In total, the section consists of two periods - $14 \mathrm{~b}$. and $8 \mathrm{~b}$., respectively (chorus sounds). The culmination comes on the words ,i Tsarstvu Yoho ne bude kintsia” (B-dur).

The third section also begins with the triple entry of the voices in the same tonality as in the first. In the words ,odnakove pokloninnia $i$ odnakova slava, shcho hovoryv cheres prorokiv" the composer makes bass duplications, but only in rhythmic terms. The entire 3-part composition ends with a powerful chorus sound in G-dur.

The mystically consecrated moment of praise in the Liturgy of Skoryk is perceived by Mylist myru (11th number) - from which the Eucharistic canon begins - the culmination of the liturgy. Here the main Sacrament of the Liturgy takes place: bread and wine, after being consecrated by the Holy Spirit, become the true Body and Blood of Christ. The cry of the priest encourages us to participate with the fear of God, reverence, and with a clear conscience. The choir responds with the words: „Mylist myru, zhertvu khvalinnia”, recalling that the best sacrifice to God is repentance, humility and a merciful attitude toward others (Luke 7, 12), as well as gratitude for His love and beneficence.

The folk song complex crystallizes in thematic theme. The first section of the G- dur (15 beats) is played by tenors and bass. The divisions into phrases are applied according to the text. The initial three bars are lined up by the third (downward direction with the plugal filling at the end), sequential development. In the following fragments, in the words 
„Pidnesly do Hospoda”, „pokloniatysia Ottsu” the melody is directed upwardly (exactly according to the same principle as in „Kheruvymskii pisni"). Composer using the variability of $4 / 4$ and $3 / 4$ sizes, as if playing with two and three dimensions.

Straightening your hearts towards God, breaking away from all earthly and vain things, the continuation of prayer sounds. It is interesting that right here (at the crucial moment of the liturgy) that Skoryk interprets this canon completely freely. The next section is a continuous repetition of everything from the beginning, where the main melody remains the same, but it sounds already at the upper voices, to which the bass canton the monophonic one. In the first sentence ( 7 cycles, 4/4) the tenors enter the third only in the last cycle (A-dur). Sub-vocal polyphony of folk-song character is developing. In the following sentence (fis-moll modulation, hmoll completion, 8 beats), constant roll calls are applied to the different voices of the choir. In this way, continuous praise is expressed.

After the prayer, „Dostoino i pravedno ye," there is gratitude, expressed by the threefold pronouncement of the word ,Sviat”, indicating the threefoldness of Divine Persons. Skoryk this song is compositionally divided into two sections. The first ( 8 b.), Marked by a nuance - Maestoso quasi campane - is indeed performed as fanfare praise. In the active movement on f, 27 times „Sviat” sounds dissonantly weighty and bright. Continuous intonation overlays, in which each timbre is divided into three, with a two-long size, reproduce the sign of the cross, and lead to a filled 12-vote.

The second section „Hospod Savaof” (14 b.) in a choral presentation (E-dur, cis- moll, fis-moll, H-dur, Gis-dur, C-dur) musically expresses inner delight and splendor from excellent and wise works of God. The laudatory greeting „Osanna v vyshnikh” is framed by double prayer singing and double pronouncing the word "Amin". This expresses faith in the reality of the Last Supper, where the Lord taught His apostles the true Body and Blood.

And here comes a very important action in the Liturgy - the consecration of the Holy Gifts. The song of praise „Tebe ospivuiemo” at a pace Lento. The basic tonality of the C-dur, but the final chord is in the des-moll, the size of $4 / 4$ is maintained until the end of the piece. It all begins with a delayed note in middle voices, and in the extreme - the main melodic line. The continuation of "Tobi Diakuiemo" is performed in chorus (in a wide chord arrangement). 
Thus, at all levels of the Liturgy form, the dramatic principle of opposition and unity of the spiritual sentiments of penitence and glorification inherent in the canonical Divine-service act is manifested in many ways.

In accordance with this, the vocal-choral cyclical whole of the Liturgy is developed on the basis of a dynamic change of contrasting moments: 1) dramatic confessional, penitent on emotional fullness of episodes, and 2) prayer-contemplative appeals to God, expressing humble or enthusiastic feelings, states of prayer awe or the joyful glorification of the Lord. The result of the liturgical drama of Skoryk becomes the symbolization of the joy of purification of the repentant soul of the hero and the community related to him in the liturgical action, who, following the difficult path of sinful dramatic experiences, spiritualized with spiritual insight.

The main means of musical expression of a rich emotional range of dramatic, lyrical and contemplative moods in the Liturgy of Skoryk were: 1) generating thematic complex, stated in the Velikaya yekteniya (number 1), based on the trichordo-second intonation, diversely monothematically, variant-variational and symphonic realizable in the choral and solo-choral numbers of the cycle, as well as 2) polytonal and 3) polyharmonic complexes, which play an important formative, expressive and colorful-coloristic role.

Describing the unusual synthesis of style and genre landmarks of the Liturgy by M. Skoryk, L.O. Kyianovskaia noted: ,...The entire eidect of Ukrainian spiritual music, from ancient monodiths, whose tradition is most noticeable in the ecclesias, the brilliant ornamental baroque spiritual concert, the romantic sublime lyricism of the „Peremyskaia school”, the strict enlightenment of spiritual masterpieces of the beginning of the XX century, finds its rethinking in the liturgy" [1].

The composer, in the preface to the Liturgy, explained the individual features of the style synthesis of this spiritual and choral cycle: „I would like my religious works would be performed in the church. I know it this is still almost impossible, because there are tastes of those who manage the service ... I tried to write very clearly and focused on our party music, of course, did not ignore the legacy of Bortnianskiy and Berezovskiy. These traditions I would like to refresh with new harmonies and modulations, more unexpected and sharp. With few exceptions, I did not go beyond the canons ... Therefore, I believe that the transition from the canonical 
tradition to the newer harmonies, modulations and consonance must be gradual" [2].

In the musical text, we revealed the inheritance of characteristic Bortnianskiy, Berezovskiy, Vedel party concerts, structural and texture techniques of the party singing of the canonical text, the peculiarities of repentant party writings characteristic for party concerts.

Summarizing, we indicate only some of them - the minor (Dorian), the versatility of the intonational material, the contrasts between the parts (for example, after the through simulation, the rolls of the three-horse and the tithes), the relief climaxes, the character of the application of the dialogical structure of the text, the comparison of two ensembles of low (question) and high (emotional reaction), the use of expressive means for exacerbating drama, emphasizing the modulation transitions of a particular psychic openness. Often, it receives a vivid contrast of full sound and a trio of basses, a chord presentation and a broad melodious downward simulation. Harmony plays a big role in dramatization, especially the major trivial sequence in a minor.

Among other techniques shows the practice of party concert in the music of the Liturgy of Skoryk: the division of parts; tempo designations; the saturation of individual fragments of melody by dashed rhythm in the spirit of instrumental and concert baroque thematism; detailed dynamic shades. The texture features: singing the tricks in the two upper voices and the reference line of the bass, organ points and colored instruments are leading in the singing of the Kant.

An essential factor in the concert style is the fugato on a lengthy subject, typical of the developed free-polyphonic style. Based on the Bortnianskiy's part-concert traditions, M. Skoryk uses polyphonic forms as if he deliberately avoids traditional techniques, sometimes even to the purely symbolic use of them: in the form of folk-chorus vtor, podolosovimitations, comparisons of solo singing with chorus, tuty, etc. Thus, the implementation of the traditions of the party concert, expresses the neoclassical tendencies of M. Skoryk's work in the Liturgy.

As S. Lisetskyi notes in the article on ,stylistic tendencies of „neoclassicism" and „neo-folklorism” in the music of M. Skoryk" 60-70s of the 20th century, in Ukrainian music, is the first example of neoclassicism, representing the author's rethinking of form-forming, tonal, accord-harmonic, metro-rhythmic, polyphonic techniques of masters of Western European and national music of the twentieth century of 
P. Hindemit, S. Prokofiev, D. Shostakovich methods of working with folklore by B. Bartok, I. Stravinskyi [3].

It promotes the selection as the main source of the theme of the Liturgy M. Skoryk ritual and song-dance melos of the Carpathian region (Hutsul, Lemkivsky), starting for his Concerto for f-no and orchestra, music for the film Shadows of Forgotten Ancestors, the Carpathian Concert and the Hutsul triptych for the symphonic orchestra, Partites by M. Skoryk. The emphasis on folklore melos manifests itself in: 1) the original processional melodism based on tri-chord-tetrachordic and second-quart-triton motifs and intonations; 2) active, pulsating syncopated and dashed metroreghythmic formulas; 3) specific diatonic mod-tone modulus, which enables the thematic material to be deployed into polytonal and composite-type fabrics [4].

Conclusions. The musical material of the Liturgy is strikingly original, individualized and at the same time typical for modern music, phonically bright and expressive non-tactile accordion. At the same time, the supporting logical role of the classic tertz chord, which has signs of popular harmony, is preserved. There are also distinct T-D-ings, which often appear in a thin and bold altered environment, in the context of a complicated, diatonic in the genesis, chromatized tonality (evidence of connection with the principles of S. Prokofiev's tonal thinking). Originally, inherent in the individual style of M. Skoryk, the combination of abundantly altered modern harmonic structures (second-quart and synthetic) with the modes of Ukrainian folk art.

Prospects for research. The appeal of M. Skoryk to the spiritual and choral genre of the Liturgy of St. Joanna Zlatoust points to a new thematic „dominant" of his choral work of the last three decades, which became an alternative to the cantatas of the 70-80s (,Vesna”, „Chelovek"). This is the topic of searching for the spiritual and ethical foundations of being and self-determination of modern man, which was also originally implemented in a number of new spiritual and choral works of the 2000s. Those were the Spiritual Concert and the Three Psalms for poems by T.G. Shevchenko, which, revealing in many ways common stylistic, compositional and stylistic tendencies with the Liturgy, form a kind of spiritual choral macrocycle. The study of these spiritual and choral works from the standpoint of the evolution of the composer's choral style will be the goal of our subsequent work. 


\section{Список використаних джерел і літератури:}

1. Кияновська Л. „Перемиська школа” як культурологічний феномен // Вісник Львів. ун-ту: Серія мист-во. Львів: Львів. універ, 2007. Вип. 7. С. 65-71.

2. Чекан Ю. Вступна стаття // Духовні твори М. Скорика. Київ, 2005. С. 1-8.

3. Лісецький С.Й. Стильові тенденції „неокласицизм” і „неофольклоризм” у музиці М. Скорика // Культура і сучасність: зб. нак. ст. Київ, 2016. № 1. С. $92-$ 97.

4. Пясковский І.Б. Симфонічна музика // Історія української радянської музики. Київ: Музична Україна, 1990. С. 120-128.

\section{References:}

1. Kyjanovsjka, L. (2007). „Pereymskaya school” as a cultural phenomenon. Visnyk Ljviv. un-tu, 7, 65-71 [in Ukrainian].

2. Chekan, Ju. (2005). Introductory article. Dukhovni tvory M. Skoryka, 1-8 [in Ukrainian].

3. Lisecjkyj, S.J. (2016). Stylistic tendencies of „neoclassicism” and „neo-folklorism” in the music of M. Skoryk. Kuljtura i suchasnistj, 1, 92-97 [in Ukrainian].

4. Pjaskovskyj, I.B. (1990). Symphonic music. Istorija ukrajinsjkoji radjansjkoji muzyky, 120-128 [in Ukrainian]. 